\title{
RAHANIMETUS ROBI
}

\author{
IRIS METSMÄGI
}

Annotatsioon. Artiklis esitatakse vanast kirjakeelest tuntud sõnale robi '(väike) rahaühik või münt' vene laenuetümoloogia, < дробь 'haavlid; killud, puru jne'. Osutatakse, et sama tüvi robi võib olla säilinud tänapäeva eesti keeles esinevates taimenimetustes robirohi ja robihein.

Võtmesõnad: eesti keel, eesti vana kirjakeel, vene laenud, taimenimetused, leksikoloogia, etümoloogia

Sõna robi 'vanaaegne (väike) rahaühik või münt' on arhailine. Peamiselt on sõna kasutatud XVII sajandi kirjakeeles, hilisemad andmed selle kohta on aga napid ning viimastest õigekeelsussõnaraamatutest (nt ÕS 1999, ÕS 2006, ÕS 2013) sõna ei leiagi. „Eesti keele seletavas sõnaraamatus“ on robi mainitud tähenduses küll ära toodud, kuid ei ole esitatud ühtki kasutusnäidet (vt EKSS 4: 861). Sõna päritolu pakub siiski huvi vähemalt kahel põhjusel. Esiteks on sel kindel etümoloogiline vaste soome keeles, vrd sm ropo 'veering, kross, penn; vähene and'. Teiseks pole võimatu, et sama tüvi on säilinud liitsõnalises taimenimetuses robirohi (Rhinanthus), üldkeeles ka robihein (vt EKSS 4: 861-862; ÕS 2013: 790). Sõna robi on käsitletud ka kõikides soome ja eesti etümoloogiasõnaraamatutes (vt SKES III: 838; EEW VIII: 2509-2510; SSA 3: 92; Häkkinen 2004: 1061; EES: 432).

XVII sajandi kirjakeeles on sõna robi väikese rahaühiku või mündi tähenduses kasutanud mitmed autorid, näiteid on nii põhja- kui ka lõunaeestikeelsetest tekstidest ${ }^{1}$.

Philippus kostis ninck laus temma wasto: Kattesadda robbe ehst leiba ei olle mitte küll neine sean .. Jh 6:7 (Rossihnius 1898/1632: 101)

Näidete otsimisel on kasutatud vana kirjakeele korpuse (VAKK) ja Eesti piiblitõlke ajaloolise konkordantsi (EPTK) abi. 
.. sinna ei sah sählt enne mitte welja tullema, senni kui sinna se wihmse robbi erramassat. Mt 5:26 (Rossihnius 1898/1632: 128).

Philippus kostas temmal / kahesadda robbi ehs leiba ep olle mitte kül neile ... Jh 6:7 (Stahl 1638 HH3: 55)

.. sinna ep saht sehlt mitte welja tullema / kunni sinna kahs se wihmbse robbe maxat. Mt 5:26 (Stahl 1638 HH3: 104)

Eps kax warblaset ostataxe öhe robbi ehs? Mt 10:29 (Stahl 1638 HH4: 149).

.. ei sah s. sählt mitte erratulla, sehni Kun s. sedda wihmaze robbo erramassat. Mt 5:26 (Gutslaff 1647-1657: 226)

.. öhest töisest waisest Lesckest kirjotap se Evangelist Marcus / eth temma kax Robbit Jummala Kirsto sisse andnut on. (Stahl 1649: 692)

Nink ütz waine Läsk tulli nink heit katz Robbi Kirsto sisse / se om ütz Teng. Mk 12:42 (WastT: 96)

Ent temmä näggi kah ütte waist Läskä katz Robbi sinnä heitwät. Lk 21:2 (WastT: 163)

XVII sajandil on sõna kujul robbe registreeritud ka Heinrich Gösekeni sõnaraamatus, see on esitatud saksa sõnade Heller ('heller, väike münt') ja Scherff ('veering') vastena (Göseken 1660: 233, 354).

Eesti piiblitõlke ajaloolise konkordantsi (EPTK) andmetel hilisemates piiblitõlgetes sõna enam kasutatud ei ole. Vrd nt eespool olevatele näidetele vastavaid kirjakohti 1739. a piiblis (tsiteeritud EPTK järgi).

Wilippus wastas temmale: Leibo kahhe saa tenari-rahha eest ei lö mitte neile ette .. Jh 6:7

.. sinna ei peäse seält wälja, ennego sinna ka wiimse tinga saad ärramaksnud. Mt 5:26

Eks kaks warblast müda weringe eest? .. Mt 10:29

Ja üks waene lesknaene tulli, ja panni kaks weringit sisse, se on üks runstik. Mk 12:42

Agga temma näggi ka ühhe waese lesse-naese kaks weringit senna pannewad. Lk 21:2 
Rahanimetus robi puudubki Salomo Heinrich Vestringi käsikirjalises sõnaraamatus (Vestring 1998/1730) ja (tõenäoliselt sellele toetuvas) Anton Thor Helle sõnaraamatus (Helle 1732). Mõlemad autorid on aga registreerinud sõna robi (robo) taimenimetuste osana: Robbi Hein 'Das Graß u. unkraut im Korn [rohi ja umbrohi teraviljas]' (Vestring 1998/1730: 34), robbi rohhi 'Teschelkraut, bursa pastoris [? (harilik) hiirekõrv]', robbo heinad 'Raden [? (harilik) nisulill ehk (harilik) äiakas] (Helle 1732: 296). Väikese mündi tähenduses on robi lõunaeesti sõnana kirjas XVIII sajandi teisel poolel ilmunud August Wilhelm Hupeli sõnaraamatus: robbi 'ein Scherflein, kleinste Münze [veering, väike münt]' d. (Hupel 1780: 257). Ühtlasi tunneb Hupel sõna robi taimenimetuste osana: [robbi] hein 'Thaugras [? kastehein]' r./ [robbi] rohhi 'Täschelkraut [? põld-litterhein]' r./ robbo heinad 'Raden' Kr. r. (ibid.), sõnaraamatu teine väljaanne lisab neile näidetele sõna [robbi] hain 'Hahnenkamm [kukehari]' Kr. Rg. (Hupel 1818: 207; taimenimetuste registreerimise kohta vt ka Vilbaste 1993: 133, $233,528,618)$.

Wiedemanni sõnaraamatust leiab sõna robi nii mündi tähenduses kui ka taimenimetuste osana: robi G. robe (d) 'kleine Münze (=teng), Scherf' (bl), robi-hain 'Klappertopf (Rhinanthus L.) [robirohi]', r.-rohi' Täschelkraut (Thlaspi arvense L.) [põld-litterhein]'. Wiedemanni andmetel kuulub tähendus 'münt' niisiis piibli- ja kirikukeelde. Taimenimetusena on registreeritud ka robu-hein 'Klappertopf (Rhinanthus L.), Kornrade (Githago segetum Desf.) [? (harilik) nisulill ehk (harilik) äiakas]'. (Wiedemann 1973/1893: 965-966)

Eesti murretest ei ole hilisemal ajal sõna robi tähenduses '(väike) rahaühik, münt' kirja pandud. Andrus Saareste oma ,Eesti keele mõistelises sõnaraamatus" viitab kõnealuse sõna tähenduse 'väike rahaüksus muiste, teng' juures Wiedemannile ning esitab üksnes XVII sajandi kirjakeelest pärit näiteid (EKMS III: 487). Rohkem on Saarestel aga näiteid tüve robi sisaldavate taimenimetuste kohta: tema andmetel on Põhja-Eestis tuntud nimetus robirohi, Lõuna-Eestis esineb robihein või robuhein. Tüvi robi võib ka üksi esineda taimenimetusena. Kõikide variantide tähenduseks on antud 'Rhinanthus'. (EKMS III: 643, 1141) Huvitav kirjapanek on Häädemeestelt: robid 'mustad terad viljas' (EKMS III: 393).

Ka EMSUKA ja VMSi andmeil on tüvi robi Eesti murretes tuntud ainult taimenimetusena või selle osana: robi, robiein $\sim$ robihain, robirohi. Nimetused on levinud peamiselt Lõuna-Eesti murdealal ja selle vahetus 
naabruses (Häädemeeste ja Saarde murrakus Pärnumaal ning PõhjaViljandimaa murrakutes), teateid on ka Ida-Eestist (Iisaku kihelkonnast kõikidelt murdealadelt, Viru-Jaagupist ja Kodaverest), üksik teade Sõrvest (VMS II: 334; EMSUKA; vt kaart). Murdeandmed ei võimalda täpselt määrata, missuguste taimeliikide kohta neid nimetusi on kasutatud, kuid üsna tõenäoliselt on nende nimetustega tähistatud mitut liiki. Seda teemat käsitletakse lähemalt hiljem.

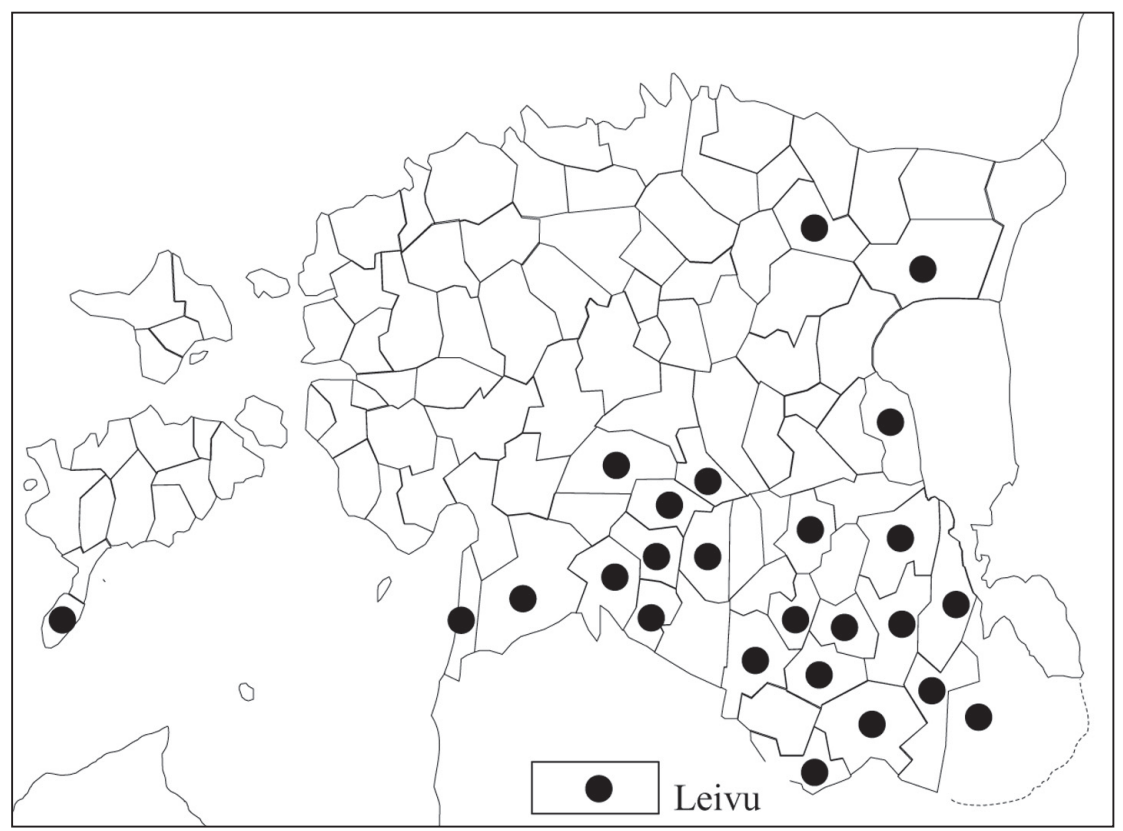

Kaart. Taimenimetused robi, robiein, robihain, robirohi Eesti murretes

SSA andmetel on soome sõna ropo ja eesti sõna robi esimest korda kõrvutatud XVIII sajandi lõpust pärinevas Christfrid Gananderi käsikirjalises sõnaraamatus (SSA 3: 92; Ganander 1997: 803). Sõnade etümoloogilises kokkukuuluvuses ei ole kahtlust, vastavus on niihästi häälikuline kui ka semantiline. Soome ropo on *oi-deminutiiv, Agricolal esineb ka rööpvariant ropoi (Mägiste 1928: 77, 105; SKES III: 838; SSA 3: 92). ${ }^{2}$ Sõnadele on välja pakutud laenuetümoloogiaid, mida etümoloogiasõnaraamatud ei

2 Julius Mägiste on tõlgendanud eesti vana kirjakeele sõnakuju robbe [robe] *ei-liitelise deminutiivina (Mägiste 1928: 15, 105). 
ole õigusega aktsepteerinud ${ }^{3}$. Soome ja eesti etümoloogiasõnaraamatud on üksmeelsed, et soome ropo, eesti robi on tõenäoliselt onomatopoeetilisdeskriptiivse päritoluga ning samatüvelised soome tegusõnaga ropista, eesti robisema (SKES: 838; EEW VIII: 2509-2510; SSA 3: 92; Häkkinen 2004: 1061; EES: 432). Rahaühiku või väikese mündi nimetus viitab seega müntide kokkupuutel tekkivale helile. Seletus ei ole veenev, kuigi ehk mitte täiesti võimatu. Nii eesti kui ka soome keeles leidub raha kohta onomatopoeetilistest tüvedest moodustatud sõnu. Võib ju eesti keeles (metall)raha nimetada kõlisevaks, paberraha aga krabisevaks. Kuid need nimetused on piltlikud ja teatava stiilivärvinguga, on kujuteldamatu, et sellist laadi nimetus võinuks sattuda näiteks piiblitõlkesse. Soome keeles on onomatopoeetilise päritoluga nimetus kolikko 'münt' (<kolista 'koliseda') võrdlemisi uus, XIX sajandi keskpaiku tarvitusele tulnud sõna (SSA 1: 389; Häkkinen 2004: 461). Enda keeletundele tuginedes söandan samuti kahelda, kas robisema on sobivaim verb müntide kokkupuutel tekkiva heli kirjeldamiseks. Samas on eesti keeles hulgaliselt mitmesuguseid rahaühikuid, eeskätt münte märkivaid laensõnu, nt keskalamsaksa laenud killing, kross, münt, penning, veering, vene laenud kopikas ja vanamoeline teng; sõna raha ise on germaani laen. Seega on põhjust oletada, et ka robi võib olla laen senitundmatust allikast.

Esitan laenuallikana vene sõna keeles on 'haavlid; murd (matemaatikas); killud, puru; põrin, tärin, klõbin, rabin; triller' (VES 1: 379). Eesti sõna häälikuline vastavus on ootuspärane. Kuigi vene sõnal ei ole otseselt tähendust '(väike) münt', võimaldab vene tüve semantika eesti (ja soome) sõna ka tähenduse poolest sellega siduda. Sama tüvi esineb tegusõnas дробить 'tükeldama, peenestama, purustama, lõhkuma, killustama; (kõnekeeles) klõbistama' ja omadussõnas дробный 'killustatud; tihe, peen' (ibid.), millel on vasteid paljudes slaavi keeltes, nt ukr дроби́ти, дрібни́й, serbohorvaadi дрообити, дроббнй, tšehhi drobiti, drobný, poola drobić, drobny (vt Vasmer 1986: 539; Černyh 2002 I: 269). Sõnapere semantika on seega seotud killustamise, peenestamise, lõhkumisega. Vastavalt on ka sõna дробъ algseim tähendus ilmselt 'killud, puru', millest on kujunenud muud, spetsiifilisemad tähendused. Semantilise seose 'killustama, tükeldama' > 'raha' paralleelina meenutatagu siinkohal, et nt

3 Näiteks on välja pakutud seost araabia sõnaga rub'îje 'teatud väike kuldmünt', pärsia sõnaga rupija jne (Paasonen 1903: 48). Samuti on pakutud seost vene sõnaga рубль 'rubla' (Ariste 1958: 27, 32). 
vene rahaühiku nimetus рубль ( $>$ eesti rubla) lähtub tegusõnast pубить 'raiuma' (vt nt Černyh 2002 II: 125-126).

Eesti robi, soome ropo semantikat silmas pidades pakuvad huvi mõned kõnealuse vene sõna vanemast keelest kirja pandud eritähendused, samuti mõne vastava tüve tuletise tähendused, mis märgivad pisemaid metall- või väärtesemeid. XI-XVII sajandi vene keele sõnaraamatu andmetel on üks sõna дробь tähendusi olnud sama, mis tuletisel дробница 'мелкие металлические пластинки или бляхи для украшения тканей [väikesed metallplaadid/-liistakud või naastud kangaste kaunistamiseks]' (SRJa XI-XVII: 356-357). Sellised kaunistused võiksid meenutada väikesi münte. Mitmuse vormis tuletis дробнúu̧ on vananenud sõnana ära toodud ka Vladimir Dahli sõnaraamatus, tähenduses 'мелкія подвьски или другія украшенья, кисточки ипр. изъ золота, каменьевъ, жемчуга [väikesed ripatsid või muud kaunistused, tupsud jne, kullast, kividest, pärlitest]', samuti leidub seal дро́бниць 'блестки золотошвейныя [kuldõmbluslitrid]' (Dahl 1955/1880-1882: 493). Vanavene keeles on tuletis дробьница tähendanud 'мелкий жемчуг [väikesed pärlid]'; sõna дробь vanavene allikates ei leidu (Černyh 2002 I: 269). XVIII sajandi keeles

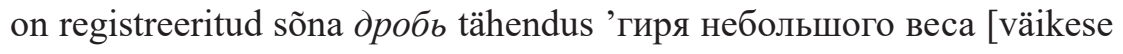
kaalu viht]', illustreerivat lauset $K$ сдгланным им въсам пуды и дроби сдълал-ли? (SRJa XVIII: 9) võiks tõlkida 'Kas tegid tema valmistatud kaalu jaoks suured ja väikesed kaaluvihid?'. Kui oletada, et siin on juttu enam-vähem sama tüüpi kaalu ja vihtide komplektist, mida mäletan kooli füüsikatundidest 1980. aastatel, võiksid väiksemad kaaluvihid, дроби, olla mündisarnased lapikud metallplaadikesed. Vene murretes esineb tuletis дробезга 'мелкие предметы; мелочь [väikesed esemed; peenraha]', nt Наменял себе дробезги, то гривенников, то пятачков 'Vahetas endale peenraha, kümne- ja viiekopikalisi' (SRNG 8: 186). On kirja pandud ka sõnaühend дробныя деньги 'мелочь [peenraha]' (Preobraženski 1959: 195). Kõnealuse slaavi tüve tuletisi kasutatakse peenraha tähenduses ka teistes slaavi keeltes, nt poola drobne (pl) 'mündid, peenraha jms' (CPE: otsisõna drobne), serbohorvaadi дро̀бйm 'мелкие деньги [peenraha]' (Černyh 2002 I: 269). Niisiis eeldab esitatud etümoloogia, et eesti robi, sm ropo tähendus 'väike rahaühik või münt' lähtub pakutud laenuallika tähendusest 'väike metallese, naast vms'.

Järgnevalt käsitlen küsimust, kas robi taimenimetustes robirohi ja robihein on sama päritoluga kui vana kirjakeele väikest rahaühikut või 
münti märkiv sõna. Sellele küsimusele ei ole üheselt kindlat vastust võimalik anda, sest on üldiselt teada, et taimenimetused on üks raskemini etümologiseeritavaid valdkondi. Olulise tähtsusega on siin kõnealuste taimede nimetamismotiiv, mille kohta on erinevaid käsitlusi. Eino Koponen peab tüve robi sisaldavate taimenimetuste seost münti märkiva sõnaga võimalikuks: robihain jne võiks olla 'rahahein', vrd sm mrd tenkaheinä, kusjuures sõna robi 'münt' sisaldab sama onomatopoeetilis-deskriptiivset tüve kui tegusõna robisema (Koponen 1998: 159). Julius Mägiste näeb aga kõnealuste taimede esmase nimetamismotiivina heli, tema järgi on robi liitsõnades robirohi, robihain algselt tähendanud 'etwas Raschelndes, raschelnd [(miski) krabisev]' ning seostub vahetult onomatopoeetilise robisema-tüvega (EEW VIII: 2509).

Ei saa eitada, et robirohu liikide nimetamisel on onomatopoeetilisel motivatsioonil teatud osa olnud. Gustav Vilbaste kirjutab perekonna Rhinanthus nimetusi kommenteerides: „Suurem osa selle perekonna taimede nimetustest on ühenduses krõbisemisega: taime vili on kotjaks paisunud tupes, mis kuivanult teeb krõbisevat häält, kui seda puudutatakse." (Vilbaste 1993: 528). See kommentaar on esitatud allmärkusena nimetuste krobisäja, kropihain, krõbiain, krõbiein, krõbinad, krõbirohi järel, mistõttu ei saa siit järeldada, et Vilbaste tingimata peaks robi-tüve sisaldavaid nimetusi seemnete krõbinale viitavaks. Nimetuste päritolu selgitamisel tuleb tema kommentaariga aga kahtlemata arvestada. Vilbaste materjalis on ka muid onomatopoeetilistest tüvedest moodustatud robirohu liikide nimetusi, nt kõrinad, kõriseja, kõristihein jne. Krõbisemisele viitavad ka nt saksakeelne nimetus Klappertopf (vrd klappern 'lõgisema, plagisema, klõbisema jne') ning vene nimetused погремок (vrd греметь 'müristama, kolistama jne') ја звонеи (vrd звенеть 'helisema, kõlisema jne').

Kuid arvestama peab sedagi, et rahvasuus ei ole nimetusi robi, robihein $\sim$ robihain, robirohi, robuhein kasutatud mitte ainult perekonna Rhinanthus liikide, vaid ka teiste taimede kohta. Gustav Vilbaste andmetel, mis muude allikate hulgas arvestavad eespool tsiteeritud Helle, Hupeli ja Wiedemanni sõnaraamatuid, on need nimetused peale perekonna Rhinanthus liikide märkinud ka taimeliike Agrostemma githago (harilik äiakas [ehk harilik nisulill]), Capsella bursa-pastoris (harilik hiirekõrv) ja Thlaspi arvense (põld-litterhein) (Vilbaste 1993: 133, 223, 528, 618). Eesti murrete arhiivi (EMSUKA) sedelitelgi on tüve robi sisaldavate taimenimetuste ladinakeelsete vastetena fikseeritud niihästi Rhinanthus $\sim$ Rhinanthus major kui 
ka Thlaspi arvense. Ühe Iisakust registreeritud teate kohaselt on robirohi Agrostemma githago. EMSUKA sedelite botaanilistesse andmetesse tuleb muidugi suhtuda ettevaatusega, sest ei ole teada, kui head teadmised olid murdeainese kogujal. Enamasti ladinakeelsed nimetused niikuinii üldse puuduvad. Üht-teist võib aga järeldada ka muu teabe põhjal, mis on robi-, robiheina- jne nimeliste taimede kohta murdekartoteegi sedelitele jäädvustatud. Neist räägitakse mitmel puhul kui põlluumbrohust, mis kasvab teravilja (pms rukki) seas ning mis rikub oma seemnetega leiva kvaliteeti. Näiteid: robirohi kasvab ikke nagu põllu pial, suvivilja ulgas IisK, robi kasvab rüän, robi teeb leiva mustas Pst, robirohi kasvab rukki ulgas, rikub leiva ära VJg, ku robihaina rüän pallo om, siss saa must leib Kan, robil um paĺlo seemend Rõu. Kuna robirohu liigid kasvavad (puis)niitudel, metsa- ja sooservadel, suur robirohi harva põllul umbrohuna, litterhein, äiakas [ehk nisulill] ${ }^{4}$ ja hiirekõrv on aga tuntud põldudel ja mujal kasvavate umbrohtudena (vt TVM: 219, 258-259, 324), siis võiksid need näitelaused käia pigem nende taimede kui robirohu (Rhinanthus) kohta. Litterheina ümaraid kõdrakesi saab kahtlemata võrrelda müntide, litrite jm sellisega. Nimetus litterhein põhinebki niisugusel võrdlusel, nagu ka mitmed teiste keelte Thlaspi arvense nimetused, nt saksa Acker-Hellerkraut (vrd Heller 'heller, väike münt'), inglise field pennycress (vrd penny 'penn'), vene rahvapärane nimetus денежник (Dahl 1955/1880-1882: 428; vrd деньги 'raha').

Viljade teatav sarnasus võib olla põhjus, miks eri taimeliike on rahvasuus nimetatud samade nimetustega. Üldiselt välimuselt on need taimed üsnagi erinevad: Thlaspi arvense ja Capsella bursa-pastoris kuuluvad ristõieliste sugukonda, Agrostemma githago nelgiliste sugukonda, perekonna Rhinanthus liigid mailaseliste sugukonda. Seega pean võimalust, et tüvi robi taimenimetustes on algselt sama mis robi 'väike rahaühik või münt', üsna arvestatavaks. Mainitagu siinkohal, et ka vene keeles esineb tüvest дроб- moodustatud taimenimetus дробница, mis märgib mailaseliste sugukonda kuuluvat pikalehist mailast (Veronica longifolia) (Dahl 1955/1880-1882: 493). Onomatopoeetilist tõlgendust, mis seostab taimenimetust robisema-tüvega ja mis kajastub nt Viljandi kihelkonnas kirja pandud robiheina kirjelduses kusa peosse võtad siss robiseb kiik (EMSUKA), võiks ehk pidada hilisemaks rahvaetümoloogiaks, mis eelkõige näitab, et sõna robi tähendus oli ähmastunud.

\footnotetext{
${ }^{4}$ Äiaka [nisulille] seemned on musta värvi ja mürgised (TVM: 324).
} 
Niisiis võib peamiselt XVII sajandi kirjakeeles esinev sõna robi 'väike rahaühik või münt' olla vene laen, laenuallikaks sõna дробь 'killud, puru', vanemas keeles ka 'naastud jms; (väike) kaaluviht'. Kui võtta aluseks Mari Musta liigitus, võiks sõna paigutada vanemate, XV-XVII sajandist pärinevate vene laenude hulka (vt Must 2000: 11). Tõenäoliselt on sama päritoluga robi taimenimetustes robirohi, robihein (Rhinanthus), rahvakeeles ka 'põld-litterhein (Thlaspi arvense)' jm, pidades silmas võimalust, et taimede nimetamismotiiviks on olnud lapikute viljade sarnasus müntidega.

\section{Lühendid}

$\mathrm{Jh}$ - Johannese evangeelium; Lk - Luuka evangeelium; Mk - Markuse evangeelium; Mt - Matteuse evangeelium

\section{Kirjandus}

Ariste, Paul 1958. Vene laensõnadest vanemas eesti kirjakeeles. - Keel ja Kirjandus $1,25-33$.

Černyh $2002=$ П. Я. Черных. Историко-этимологический словарь современного русского языка. 13560 слов. I-II. 5-е издание, стереотипное. Москва: Русский язык.

Dahl 1955 (1880-1882) = Владимир Даль. Толковый словарь живого великорусского языка. I, А-3. Москва: Государственное издательство иностранных и национальных словарей.

EES = Iris Metsmägi, Meeli Sedrik, Sven-Erik Soosaar 2012. Eesti etümoloogiasõnaraamat. Eesti Keele Instituut. Tallinn: Eesti Keele Sihtasutus.

EEW = Julius Mägiste. Estnisches etymologisches Wörterbuch. I-XII, 19821983. Helsinki: Finnisch-Ugrische Gesellschaft.

EKMS III = Andrus Saareste. Eesti keele mõisteline sõnaraamat. III, 1962. Dictionnaire analogique de la langue estonienne. Avec un index pourvu de traductions en français. (= Eesti Teadusliku Seltsi Rootsis väljaanne 3.) Stockholm: Vaba Eesti.

EKSS 4 = Eesti keele seletav sõnaraamat. 4, 2009. „Eesti kirjakeele seletussõnaraamatu" 2., täiend. ja parand. tr. Toim. Margit Langemets, Mai Tiits, Tiia Valdre, Leidi Veskis, Ülle Viks, Piret Voll. Eesti Keele Instituut. Tallinn: Eesti Keele Sihtasutus.

Ganander, Christfrid 1997. Nytt finskt lexicon. 1. Alkuperäiskäsikirjoituksesta ja sen näköispainoksesta toimittanut Liisa Nuutinen. (= Suomalaisen Kirjallisuuden Seuran toimituksija 676. Kotimaisten kielten tutkimus- 
keskuksen julkaisuja 95.) Helsinki: Suomalaisen Kirjallisuuden Seura, Kotimaisten kielten tutkimuskeskus.

Gutslaff 1647-1657 = Johannes Gutslaffi piiblitõlge 1647-1657. 2013. Koost. Maeve Leivo, Ahti Lohk, Kristiina Ross, Kai Tafenau. Tallinn: Eesti Keele Sihtasutus.

Göseken, Heinrich 1660. Manuductio ad Linguam Oesthonicam, Anführung Zur Öhstnischen Sprache, Bestehend nicht alleine in etlichen præceptis und observationibus, Sondern auch In Verdolmetschung vieler Teutschen Wörter. Reval: Adolph Simon. Faksiimile: http://www2.kirmus.ee/grafo/ index.php?ID=243.

Helle, Anton Thor 1732. Kurtzgefasste Anweisung zur Ehstnischen Sprache, in welcher mitgetheilet werden I. Eine Grammatica. II. Ein Vocabularium. III. Proverbia. IV. Ænigmata. V. Colloquia. Halle: Stephan Orban.

Hupel, August Wilhelm 1780. Ehstnische Sprachlehre fuer beide Hauptdialekte, den revalschen und doerptschen; nebst einem vollstaendigen Woerterbuch. Riga, Leipzig: Johann Friedrich Hartknoch. Faksiimile: https:// books.google.ee/books?id=RmIUAAAAQAAJ\&printsec=frontcover\& source $=\&$ redir_esc $=\mathrm{y} \# \mathrm{v}=$ onepage $\& \mathrm{q} \& \mathrm{f}=$ false.

Hupel, August Wilhelm 1818. Ehstnische Sprachlehre für die beyden Hauptdialekte, den revalschen und dörptschen, nebst einem vollständigen ehstnischen Wörterbuche. Zweyte durchgängig verbesserte und vermehrte Auflage. Mitau: J. F. Steffenhagen und Sohn. Faksiimile: http://dspace. ut.ee/handle/10062/46591.

Häkkinen, Kaisa 2004. Nykysuomen etymologinen sanakirja. Juva: WSOY.

Koponen, Eino 1998. Eteläviron murteen sanaston alkuperä. Itämerensuomalaista etymologiaa. (= Suomalais-Ugrilaisen Seuran toimituksia 230.) Helsinki: Suomalais-Ugrilainen Seura.

Must, Mari 2000. Vene laensõnad Eesti murretes. Tallinn: Eesti Keele Sihtasutus.

Mägiste, Julius 1928. oi-, e ei-deminutiivid läänemeresoome keelis. Läänemeresoome nominaaltuletus I. Mit einem Referat: Die ori-, e $i$-Deminutiva der ostseefinnischen Sprachen. (= Acta et Commentationes Universitatis Tartuensis (Dorpatensis) B XII, 2.) Tartu.

Paasonen, H[eikki] 1903. Die sogenannten Karataj-mordwinen oder Karatajen. (= Suomalais-Ugrilaisen Seuran Aikakauskirja 21, 1.) Helsinki.

Preobraženski $1959=$ А. Г. Преображенский. Этимологический словарь русского языка. I, А-О. Москва: Государственное издательство иностранных и национальных словарей. [1910-1914 ја 1949 osadena ilmunud sõnaraamatu faksiimiletrükk.]

Rossihnius, Joachim 1898 (1632). Südestnische Uebersetzung des Lutherischen Katechismus, der Sonntags-Evangelien und -Episteln und der Leidensgeschichte Jesu nebst einem Anhang in das Südestnische übersetzter 
Kirchenlieder und Stücke der Agende mit einer Einleitung von Wilhelm Reiman. (= Verhandlungen der Gelehrten Estnischen Gesellschaft 19.) Jurjew (Dorpat). Faksiimile: http://dspace.ut.ee/handle/10062/19370.

SKES $=$ Yrjö H. Toivonen, Erkki Itkonen, Aulis J. Joki. Suomen kielen etymologinen sanakirja. I-VII, 1955-1981. (= Lexica Societatis Fenno-Ugricae XII, 1-7. Tutkimuslaitos „Suomen Suvun“ julkaisuja III. Kotimaisten kielten tutkimuskeskuksen julkaisuja 2.) Helsinki: Suomalais-Ugrilainen Seura.

SRJa XI-XVII = Словарь русского языка XI-XVII вв. 4 (Г-Д), 1977. Глав. ред. Степан Г. Бархударов. Академия наук СССР, Институт русского языка. Москва: Наука.

SRJa XVIII = Словарь русского языка XVIII века. 7 (Древо-Залеж), 1992. Глав. ред. Юрий С. Сорокин. Академия наук СССР, Институт русского языка. Санкт-Петербург: Наука.

SRNG 8 = Словарь русских народных говоров. 8 (Дер-ерепениться), 1972. Глав. ред. Федот П. Филин. Академия наук СССР, Институт русского языка. Ленинград: Наука.

SSA = Suomen sanojen alkuperä. Etymologinen sanakirja. 1-3, 1992-2000. Päätoim. Erkki Itkonen, Ulla-Maija Kulonen. (= Suomalaisen Kirjallisuuden Seuran toimituksia 556. Kotimaisten kielten tutkimuskeskuksen julkaisuja 62.) Helsinki: Suomalaisen Kirjallisuuden Seura, Kotimaisten kielten tutkimuskeskus.

Stahl 1638 HH3 = Heinrich Stahl. Hand und Haussbuches Für die Pfarherren und Hauss-Väter Esthnischen Fürstenthumbs, Dritter Theil, Darinnen die gewöhnliche Evangelia und Episteln durchs gantze Jahr, zusampt der Historia des bittern Leidens und Sterbens unsers Herrn Jesu Christi. Revall. Faksiimile: http://www.digar.ee/arhiiv/nlib-digar:115735.

Stahl 1638 HH4 = Heinrich Stahl. Hand- und Haussbuches Für die Pfarherren und Hauss-Väter Esthnischen Fürstenthumbs, Vierdter und Letzter Theil, Darinnen I. 14. Psalmen Davids, II. Etliche Gebete, III. Unterschiedliche Gewissens Fragen, IV. Bericht wie mit Schwermütigen, Angefochtenen, Krancken, Sterbenden, Ubelthätern zu handeln, V. Texte zu HochzeitTauff- und Leich-Predigten, Ausz Gottes Wort und Reinen KirchenLehrern zusammen getragen. Revall. Faksiimile: http://www.digar.ee/ arhiiv/nlib-digar:102283.

Stahl, Heinrich 1649. Leyen-Spiegels, Darinnen kürtzlich gezeiget wird, wie ein einfältiger Christ Die Fest- und Sontägliche Evangelia in reiner Lehr und heiligem Leben Jhm zu nütze machen kan, Sommer-Theil. Reval. Faksiimile: http://www.digar.ee/arhiiv/nlib-digar:102275.

TVM = Taimede välimääraja. Käsiraamat kõrgemate taimede tundmaõppimiseks. 1972. Tallinn: Valgus. 
Vasmer 1986 = Макс Фасмер. Этимологический словарь русского языка. I (А-Д). Издание второе, стереотипное. Перевод с немецкого и дополнения члена-корреспондента АН СССР О. Н. Трубачева. Под редакцией и с предисловием проф. Б. А. Ларина. Москва: Прогресс.

VES 1 = Vene-eesti sõnaraamat. Русско-эстонский словарь. 1, 2000. Teine, parand. tr. Toim. Helle Leemets, Henn Saari, Rein Kull. Eesti Keele Instituut. Eesti Keele Sihtasutus.

Vestring, Salomo Heinrich 1998 (1730). Lexicon Esthonico Germanicum. Tartu: Eesti Kirjandusmuuseum.

Vilbaste, Gustav 1993. Eesti taimenimetused. Nomina vernacula plantarum Estoniae. (= Emakeele Seltsi toimetised 20 (67).) Tallinn: Eesti Teaduste Akadeemia.

VMS II = Väike murdesõnastik. II, 1989. Toim. Valdek Pall. Eesti NSV Teaduste Akadeemia Keele ja Kirjanduse Instituut. Tallinn: Valgus. http://www. eki.ee/dict/vms/.

Wast $\mathbf{T}=$ Meije Issanda Jesusse Kristusse Wastne Testament, Echk Jummala Pöha Sönna, kumb Perräst ISSANDA JESUSSE KRISTUSSE Sündmist põhist Ewangelistist nink Apostlist om ülleskirjotetu. 1686. Riga: Wilcken. Faksiimiletrükk: Wastne Testament 1686. 2001. Eesti Keele Instituut, Eesti Keele Sihtasutus.

Wiedemann, Ferdinand Johann 1973 (1893). Eesti-saksa sõnaraamat. Neljas, muutmata trükk teisest, Jakob Hurda redigeeritud väljaandest. Tallinn: Valgus.

ÕS 1999 = Eesti keele sõnaraamat ÕS 1999. Eesti Keele Instituut. Toim. Tiiu Erelt. Koost. Tiina Leemets, Sirje Mäearu, Maire Raadik, Tiiu Erelt. Tallinn: Eesti Keele Sihtasutus.

ÕS 2006 = Eesti õigekeelsussõnaraamat ÕS 2006. Eesti Keele Instituut. Toim. Tiiu Erelt. Koost. Tiiu Erelt, Tiina Leemets, Sirje Mäearu, Maire Raadik. Tallinn: Eesti Keele Sihtasutus.

ÕS 2013 = Eesti õigekeelsussõnaraamat ÕS 2013. Eesti Keele Instituut. Toim. Maire Raadik. Koost. Tiiu Erelt, Tiina Leemets, Sirje Mäearu, Maire Raadik. Tallinn: Eesti Keele Sihtasutus.

\section{Sõnavarakogud ja võrgumaterjalid}

CPE $=$ Cambridge Dictionary. Polish-English Dictionary. https://dictionary. cambridge.org/dictionary/polish-english/.

EMSUKA = Eesti murrete ja soome-ugri keelte arhiiv Tallinnas Eesti Keele Instituudis.

EPTK = Eesti piiblitõlke ajalooline konkordants. http://www.eki.ee/piibel/. VAKK = Vana kirjakeele korpus. http://vakk.ut.ee/. 


\title{
Estonian coin name robi
}

\author{
IRIS METSMÄGI
}

The Estonian word robi 'ancient small coin, penny' has mainly been used in 17th century religious texts. The word also has an equivalent in Finnish, cf. Finnish ropo 'small coin, penny; scanty donation'.

So far, it has been accepted that the word robi is etymologically related to the Estonian onomatopoetic verb robisema 'to rustle, to rattle', Finnish ropista. In the present article, a Russian loan source is suggested, < Russian дробь 'small shot; fraction (in mathematics); splinters, broken pieces, crumbs', in older language also '(metal) plaques; (small) weight', cf. also дробить 'to crush, to break to pieces, to divide up, to split up', дробный 'separate, subdivided, split up'. The word robi could belong to the older (15th-17th century) Russian loanwords in Estonian.

The same word probably occurs in the compound plant names robirohi, robihein 'rattle (Rhinanthus)', in historical dictionaries and in dialects also 'field pennycress (Thlaspi arvense)' etc., considering that the naming motive of the plants is the similarity of flat fruits and small coins.

Keywords: Estonian, old literary Estonian, Russian loanwords, plant names, lexicology, etymology

Iris Metsmägi

eesti keele ajaloo, murrete ja soome-ugri keelte osakond

Eesti Keele Instituut

Roosikrantsi 6

10119 Tallinn

iris.metsmagi@eki.ee 